\title{
Co-infection with Trichodina (Ciliophora: Trichodinidae) and Aeromonas caviae synergistically changes the hematology and histopathology of Asian seabass Lates calcarifer
}

\author{
SUFARDIN ${ }^{1, \bullet}$, SRIWULAN ${ }^{2, \bullet \bullet}$, HILAL ANSHARY ${ }^{2, \bullet \bullet \bullet}$ \\ ${ }^{1}$ Department of Fisheries, Faculty of Marine Science and Fisheries, Universitas Hasanuddin. Jl Perintis Kemerdekaan Km. 10, Makassar 902425, South \\ Sulawesi, Indonesia. Tel./fax.: +62-411-586025, •email: sufardin181@ student.unhas.ac.id \\ ${ }_{2}^{2}$ Parasite and Fish Disease Laboratory, Faculty of Marine Science and Fisheries, Universitas Hasanuddin. Jl Perintis Kemerdekaan Km. 10, Makassar \\ 902425, South Sulawesi, Indonesia. Tel./fax.: +62-411-586025, •vemail: sriwulan@unhas.ac.id; •vvemail: hilalanshary@unhas.ac.id
}

Manuscript received: 12 April 2021. Revision accepted: 23 July 2021

\begin{abstract}
Sufardin, Sriwulan, Anshary H. 2021. Co-infection with Trichodina (Ciliophora: Trichodinidae) and Aeromonas caviae synergistically changes the hematology and histopathology of Asian seabass Lates calcarifer. Biodiversitas 22: $3371-3382$. Consequential interaction contributed by parasitic and bacterial infections in fish has received little attention and impact of co-infection is mostly undescribed. This study identifies and describes notable damage arising from the co-infection of Trichodina and Aeromonas caviae infecting the seabass Lates calcarifer. A completely randomized experiment was performed with 4 infection treatments (healthy fish; fish naturally infected with Trichodina sp.; healthy fish injected with A. caviae; fish naturally infected with Trichodina sp. and injected with A. caviae) and 3 replicates. Fish were obtained from the Takalar Brackish Aquaculture Institute, South Sulawesi, Indonesia. The data were statistically tested using linear regression analysis. The results showed bacterial pathogenicity, lymphocyte percentage, and histopathological quantification were statistically different $(\mathrm{P}<0.05)$. Meanwhile, the number of erythrocytes and leukocytes, the percentages of monocytes and neutrophils were not significantly different $(\mathrm{P}>0.05)$ between treatments. The noninfected fish showed no cell inflammation and necrosis, very little hemorrhage (liver and gills), negligible hemorrhage and melanomacrophages (kidney). Kidneys and liver were the most damaged organs of co-infected fish, with a large number of inflammatory cells, hemorrhages, vacuoles, melano-macrophages, scar tissue, inflammation and necrosis. Infection with Trichodina sp. presented less damage than the co-infection of A. caviae and Trichodina sp. In conclusion, single infection showed a mild pathological impact, meanwhile, the co-infection of Trichodina sp and A. caviae contribute significantly to fish's health.
\end{abstract}

Keywords: Cultured fish, multiple infections, pathogen bacteria, Trichodiniasis

\section{INTRODUCTION}

Seabass (Lates calcarifer) has become one of the important commodities farmed in several Asian countries, including Indonesia, due to its very high economic potential (Maharajan et al. 2016). However, technical issues and parasitic diseases are still haunting the development of seabass farming in several Indonesian coastal areas (Irmawati et al. 2020). For instance, parasite outbreaks in farmed seabass have been reported from several farms in Gerokgak, Bali (Zafran et al. 2019).

Trichodina is an ectoparasite frequently found infecting both freshwater and marine fish around the world (Wang et al. 2017). It has a clinging attack mode, attaching itself to the skin and gills (Tantry et al. 2016). Ectoparasite infestation in fish can severely damage the fish skin and facilitate other pathogens such as bacteria and viruses to enter and infect affected fish (Xu et al. 2012; Xu et al. 2014).

Zoonotic-pathogenic bacteria, including Aeromonas hydrophila, have been found in the aquatic environment (Ibraheem et al. 2017). In fish farming, Aeromonas bacteria are considered a major threat and easily spread through lesions and are known to cause diseases such as hemorrhagic septicemia (Austin and Austin 2012). They act as a pathogen in many reported cases of fish mortality which have had a significant negative impact on global fish farming (Yu et al. 2015).

Ciliated Trichodina infection has brought inevitable economic losses in aquaculture (Martins et al. 2015), including in Indonesia, yet specific descriptions of specific damage to infected fish are scarce. Furthermore, the interaction between ectoparasite and bacterial infestations in fish and possible epidemic impacts are not well understood (Abdel-Latif et al. 2020). In fact, the effects of co-infection with Trichodina as an agent that facilitates secondary bacterial infection are still unreported and unknown. Therefore, studying the co-infection of Trichodina and Aeromonas on seabass is important to provide information on the pathogenicity level of these pathogens and prepare strategic treatment plans.

This study investigates the health consequences, represented by the hematology and systemic histopathological features of organs, arising from the coinfection of Trichodina sp. and A. caviae in the seabass $L$. calcarifer. This study also provides an overview of the pathogenicity of $A$. caviae and explains the specific impact of Trichodina sp. infestation on seabass L. calcarifer. 


\section{MATERIALS AND METHODS}

\section{Time and study location}

This research was conducted from October 2020 to February 2021. Fish samples were obtained from the Takalar Brackish Aquaculture Institute, South Sulawesi, Indonesia. Fish were reared and treatments were applied in the hatchery facility, while parasites and bacteria were cultured at the Parasite and Fish Diseases Laboratory, Marine Science and Fisheries Faculty, Hasanuddin University, Makassar.

\section{Experimental design}

The study used twelve 40-liter aquaria equipped with filtration and aeration. A completely randomized design (CRD) was applied with 4 infection treatments $(\mathrm{A}=$ control or healthy fish; $\mathrm{B}=$ fish naturally infected with Trichodina sp.; $\mathrm{C}=$ healthy fish injected with $A$. caviae; $\mathrm{D}=$ fish naturally infected with Trichodina sp. and injected with $A$. caviae) with 3 replicates. Initial observation of Trichodina sp. was performed for treatments B and D to ensure that the fish had been infected as expected with the ectoparasite. Fish not infected with Trichodina sp. were obtained from different culture tanks. Each aquarium contained 8 fish (sized 8-10 cm) which were fed with commercial feed (KAIO with $50 \%$ protein) 3 times per day for 4 weeks. Before treatment $\mathrm{C}$ and $\mathrm{D}$ could be carried out, the pathogenicity and the lethal concentration $\left(\mathrm{LC}_{50}\right)$ of the bacteria need to be determined by intramuscular-injection with A. caviae of healthy (C) and fish infected with Trichodina sp. (D), to ensure at least half the test fish could survive the bacterial concentration injected. Injections were performed at bacterial concentrations of $10^{5}, 10^{7}$, and $10^{9}$ $\mathrm{CFU} / \mathrm{mL}$, with 3 replicates each for each concentration. The $\mathrm{LC}_{50}$ calculated based on these tests was used for injecting the fish in treatments $\mathrm{C}$ and $\mathrm{D}$.

\section{Parasite examination}

At the start of the study, the fish were measured $(\mathrm{cm})$ and weighed $(\mathrm{g})$, and examined using the smear method to find out whether they were infested with Trichodina sp. with three replicates for each treatment. A small amount of sample tissue was obtained by scraping the infested surface of the body, fins, or gills and placed on a slide glass. A few drops of normal saline or water from the aquaria were added and spread out. A cover glass was placed over the slide which was then observed under a compound microscope (CX21FS1 Olympus, Germany). The fish found to be infected with Trichodina sp. were placed in the aquaria for treatments $\mathrm{B}$ and $\mathrm{D}$, while non-infected fish were placed into aquaria for treatments $\mathrm{A}$ and $\mathrm{C}$.

\section{Bacterial preparation and injection}

Bacterial solutions were prepared at various concentrations $\left(10^{5}, 10^{7}\right.$, and $\left.10^{9} \mathrm{CFU} / \mathrm{mL}\right)$. The standard solution of $0.5 \mathrm{McF}$ arland (blank solution) was prepared by comparing sulfuric acid $\left(\mathrm{H}_{2} \mathrm{SO}_{4}\right)$ and barium chloride $\left(\mathrm{BaCl}_{2}\right)$ in 10 consecutive test tubes, and the bacterial concentration was determined based on that standard. The 24-hour old bacteria were then placed in Tryptic Soy Agar
(TSA) slant agar using a sterile inoculating loop and then homogenized in a test tube containing $9 \mathrm{~mL}$ of $0.9 \% \mathrm{NaCl}$ physiological solution. The turbidity of the blank solution and the bacterial suspension was measured using a spectrophotometer at $640 \mathrm{~nm}$ wavelength.

The turbidity of the blank solution was assayed to create a standard curve and generate a regression formula. The density of bacterial suspension was then calculated by substitution into the regression formula generated by the standard curve. The suspension densities obtained were diluted using $\mathrm{NaCl}$ physiological solution to obtain the expected densities $\left(10^{9}, 10^{7}\right.$, and $\left.10^{5} \mathrm{CFU} / \mathrm{mL}\right)$. Aliquots of $0.2 \mathrm{~mL}$ of each suspension were injected through intraperitoneal injection into fish reared under the appropriate treatments ( $\mathrm{Li}$ et al. 2011). The fish that died during the trial were counted to calculate the $\mathrm{LC}_{50}$ of $A$. caviae to be applied in the co-infection study.

\section{Observation of fish behavior}

Fish physiology was observed for the initial week of the experiment by following (Mangunwardoyo et al. 2010, SKBKIPM 2015). Direct and periodic observations were made of fish behavior such as swimming behavior, gill movement, and response to feeding. Fish becoming lethargic is considered an initial sign of stress, e.g. spending more time at the bottom of the tank or lolling against the wall rather than swimming in the middle of the tank. After that, abnormal behaviors were observed such as difficulty in swimming as fish begin to spend an abnormal amount of time near the surface of the tank, also occasional swimming up and down with changes in appetite. Thereafter, the stressed fish exhibited behavior such as swimming quickly or erratically around the tank and a lack of appetite. Further changes in behavior included unusually rapid gill movement, which is a sign of stress fish. Eventually, seizures or erratic movements occurred, with fish seeming to gasp for oxygen at the surface of the tank preceded death. Clinical symptoms were also observed such as swelling and bleeding. Fish behavior was watched for two hours every six hours and recorded based on the form behavior change for all treatments. Additionally, the observation of fish behavior was carried out by counting the number of fish with changed behavior, presented as a percentage.

\section{Blood profile observation}

At the end of the experiment, an amount of $3 \mathrm{~mL}$ of fish blood per sample was taken for hematology analysis (blood cell count and leukocyte differentiation) with three replicates for each treatment. Blood samples were obtained by inserting a sterile syringe into the caudal blood vessels and placed into microfuge tube containing $3.8 \%$ sodium citrate as an anticoagulant agent. Hematological parameters were expressed in international standards (IS), namely red blood cell and white blood cell counts (RBC; $10^{10} \mathrm{~mm}^{-3}$ and WBC; $10^{8} \mathrm{~mm}^{-3}$, respectively) using standard Neubauer-hemocytometry (Goda et al. 2020).

Aliquots of the isolated blood samples were taken for erythrocyte observation by filling a Thoma erythrocyte pipette up to the 1-limit and diluting with Hayem's solution to the 101-limit. Samples were observed under a 
microscope using a hemocytometer covered with a cover glass. For leukocyte observation, a leukocyte Thoma pipette was filled from the blood sample to the 0.5-limit and Turk's solution was added to the 11-limit. Blood sample drops were dripped onto a hemacytometer and slowly covered with the cover glass to avoid trapped air forming bubbles. The formula used to calculate erythrocyte and leukocyte cell counts was:

(Total Erythrocytes or Leukocytes)=Number of cells $\mathrm{x} \frac{1}{\text { Volume of examined box }} \mathrm{x}$ Number of boxes

Blood sample drops were dripped onto a glass slide for leukocyte differentiation observation. Another slide glass was prepared and placed over the glass with the blood sample at an angle of $30-45^{\circ}$. The top glass was then slowly pulled left-to-right to form a thin layer, and then both glasses were air-dried. The glasses were immersed in a methanol solution for 5 minutes followed by Giemsa dye for 20 minutes and then rinsed using running water. The prepared samples were then observed under a microscope. The leukocyte differentiation was expressed in percent.

\section{Histopathological examination}

The histopathological analysis was performed at the end of the experiment by following Espinosa et al. (2019). Fish gills, liver, kidney, skin, and muscles were sampled from fish that were randomly selected from each treatment. Organ samples were preserved in $10 \%$ neutral buffered formalin for 24 hours and washed using a physiological solution $(0.9 \% \mathrm{NaCl})$. The material was dehydrated using alcohol (70-100\%), cleaned using xylol, and embedded in paraffin. Sections were cut with a thickness of $3 \mu \mathrm{m}$, dewaxed, rehydrated, and stained using hematoxylin-eosin (HE). The tissue sections were studied under a light microscope which covers pathological alteration.

\section{Ethics}

This research has been approved by the Health Research Ethics Committee of the Faculty of Public Health, Hasanuddin University, Makassar, Indonesia with the attached number 3649/UN4.14.1/TP.02.02/2021.

\section{Data analysis}

All data collected were statistically tested using linear regression analysis to test for variance and the effect of the independent variables (fish size and bacteria concentrate on each treatment) on the dependent variable (parasite intensity, erythrocyte and leukocyte counts, leukocyte differentiation, Aeromonas pathogenicity, and histopathological quantification). All statistical analyses were performed in IBM SPSS 25.0.

\section{RESULTS AND DISCUSSION}

\section{Water quality parameters}

Water quality parameters included as supporting data were: salinity range $33-35 \mathrm{ppt}$, temperature $27-30^{\circ} \mathrm{C}, \mathrm{pH} 7-$ 8, DO 6.2-7.8 ppm, and ammonia 0.2-0.3 ppm (Table 1).

\section{Trichodina sp. infestation}

The appearance of the ectoparasites is shown in Figure 1. Observation confirmed patchy ectoparasite infestation on the gills with a prevalence of $100 \%$ for both treatments (B and D) (Table 2, Figure 2). Ectoparasite means intensity was not statistically different between the two treatments (range at 143 - 209.75 parasites/fish; $\mathrm{P}>0.05$ ) (Figure 2).

\section{Pathogenicity and $\mathrm{LC}_{50}$ of $\boldsymbol{A}$. caviae}

Pathogenicity of $A$. caviae was observed in treatments with and without Trichodina sp. Infection (Tables 3, 4, and Figure 3). The mortality rate of fish naturally infected with Trichodina sp. and injected with A. caviae (30\% max.) was higher than those single infected by $A$. caviae $(16.67 \%$ max.). The lethal concentration of $A$. caviae was higher in healthy fish $\left(10^{6} \mathrm{CDFU} / \mathrm{mL}\right)$ than in fish co-infected with Trichodina sp. $\left(10^{5} \mathrm{CFU} / \mathrm{mL}\right)$. This shows A. caviae as being more lethal in a multiple infection context than as the sole infection.

Statistical tests confirmed significant differences in pathogenicity of A. caviae (\% mortality) between fish infected by $A$. caviae alone and fish co-infected by $A$. caviae and Trichodina sp. $(\mathrm{P}<0.05)$ with a good model indicated by the coefficient of determination are close to 1 (0.81), which means it has a strong relationship between the independent and dependent variables. Additionally, the calculated $\mathrm{F}>$ the $\mathrm{F}$ table, which means the independent variable has a significant effect on the dependent variable. The fish mortality rate due to A. caviae infection was applied to obtain the lethal concentration $\left(\mathrm{LC}_{50}\right)$, giving $10^{6}$ $\mathrm{CFU} / \mathrm{mL}$ for $A$. caviae infection and $10^{5} \mathrm{CFU} / \mathrm{mL}$ for $A$. caviae and Trichodina sp. co-infection (Tables 3 and 4).

Table 1. Mean of water quality parameters during the experiment

\begin{tabular}{|c|c|c|c|c|c|c|c|c|c|c|c|c|}
\hline \multirow{2}{*}{ Parameter } & \multicolumn{12}{|c|}{ Treatment code } \\
\hline & A3 & A2 & C2 & C1 & A1 & C3 & B3 & B2 & D2 & D1 & B1 & D3 \\
\hline Salinity (ppt) & 34 & 35.25 & 33.75 & 34.25 & 35 & 34 & 34 & 35 & 34 & 35 & 35 & 35 \\
\hline Temperature $\left({ }^{\circ} \mathrm{C}\right)$ & 28 & 29 & 28 & 27 & 28 & 29 & 30 & 27 & 27 & 29 & 28 & 29 \\
\hline Potential Hydrogen $(\mathrm{pH})$ & 7 & 7 & 7.25 & 7.75 & 7.75 & 7 & 8 & 7 & 7 & 7 & 7 & 7 \\
\hline Dissolved Oxygen (DO, ppm) & 7.45 & 7.8 & 6.8 & 7.4 & 7.3 & 7.8 & 6.7 & 6.2 & 6.6 & 7.4 & 6.6 & 7.4 \\
\hline Ammonia $\left(\mathrm{NH}_{3}, \mathrm{ppm}\right)$ & 0.03 & 0.03 & 0.02 & 0.02 & 0.02 & 0.02 & 0.02 & 0.02 & 0.02 & 0.03 & 0.02 & 0.02 \\
\hline
\end{tabular}

Note: A. Control or healthy fish; B. Fish naturally infected with Trichodina sp.; C. Healthy fish injected with A. caviae; D. Fish naturally infected with Trichodina sp. and injected with A. caviae 
Table 2. Infestation of Trichodina sp. with $100 \%$ prevalence in treatments (B) and (D). No visible ectoparasite was confirmed in the control (A) and treatment (C)

\begin{tabular}{ccccccc}
\hline \multirow{2}{*}{ Fish no. } & \multicolumn{9}{c}{ Treatment code } \\
\cline { 2 - 7 } & B3 & B 2 & D2 & D1 & B1 & D3 \\
\hline 1 & 201 & 123 & 157 & 196 & 133 & 139 \\
2 & 213 & 214 & 116 & 134 & 108 & 139 \\
3 & 134 & 156 & 122 & 237 & 106 & 165 \\
4 & 125 & 175 & 145 & 226 & 160 & 201 \\
5 & 152 & 154 & 115 & 214 & 182 & 158 \\
6 & 167 & 172 & 215 & 225 & 101 & 132 \\
7 & 190 & 146 & 145 & 231 & 1203 & 123 \\
8 & 122 & 168 & 129 & 209.75 & 140.25 & 167 \\
Mean Intensity & 163.00 & 163.50 & 143.00 & $( \pm 11.60)$ & $( \pm 13.37)$ & $( \pm 8.87)$ \\
$( \pm$ SE) & $( \pm 12.52)$ & $( \pm 9.32)$ & $( \pm 11.60)$ & & &
\end{tabular}

Table 3. Pathogenicity of Aeromonas caviae infection on seabass Lates calcarifer

\begin{tabular}{ccccccc}
\hline \multirow{2}{*}{ A. caviae $](\mathbf{C F U} / \mathbf{m L})$} & \multicolumn{3}{c}{ Number of fish (ind.) } & \multicolumn{2}{c}{ Mortality } & \multirow{2}{*}{ LC } \\
\cline { 2 - 6 } & Examined & Died & Survived & Ratio & 0.00 & \\
\hline Control & 30 & 0 & 30 & $0 / 30$ & 3.33 & 6.0 \\
$1.3 \times 10^{5}$ & 30 & 1 & 29 & $1 / 30$ & 6.67 \\
$1.3 \times 10^{7}$ & 30 & 2 & 28 & $2 / 30$ & 16.67 \\
$1.3 \times 10^{9}$ & 30 & 5 & 25 & $5 / 30$ & \\
\hline
\end{tabular}

Table 4. Pathogenicity of Aeromonas caviae on seabass Lates calcarifer with Trichodina sp. co-infection

\begin{tabular}{ccccccc}
\hline \multirow{2}{*}{ [A. caviae] $\mathbf{( C F U / m L )}$} & \multicolumn{3}{c}{ Number of fish (ind.) } & \multicolumn{2}{c}{ Mortality } & \multirow{2}{*}{ LC } \\
\cline { 2 - 6 } & Examined & Died & Survived & Ratio & \% \\
\hline Control & 30 & 0 & 10 & $0 / 30$ & 0.00 & \\
$1.3 \times 10^{5}$ & 30 & 3 & 27 & $3 / 30$ & 10.00 & 5.0 \\
$1.3 \times 10^{7}$ & 30 & 7 & 23 & $7 / 30$ & 23.33 & 30.00 \\
$1.3 \times 10^{9}$ & 30 & 9 & 21 & $9 / 30$ & \\
\hline
\end{tabular}

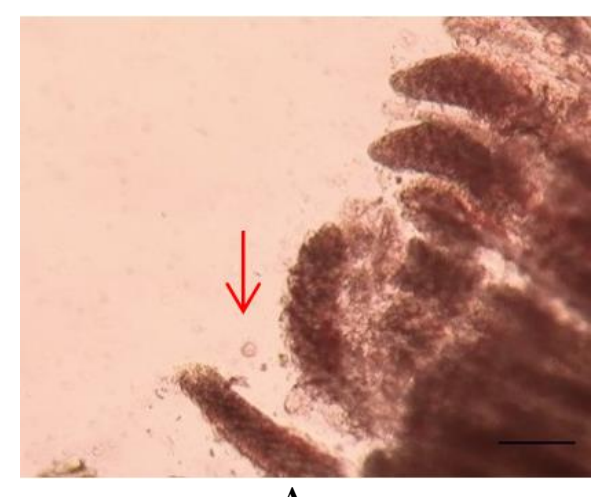

$\mathbf{A}$

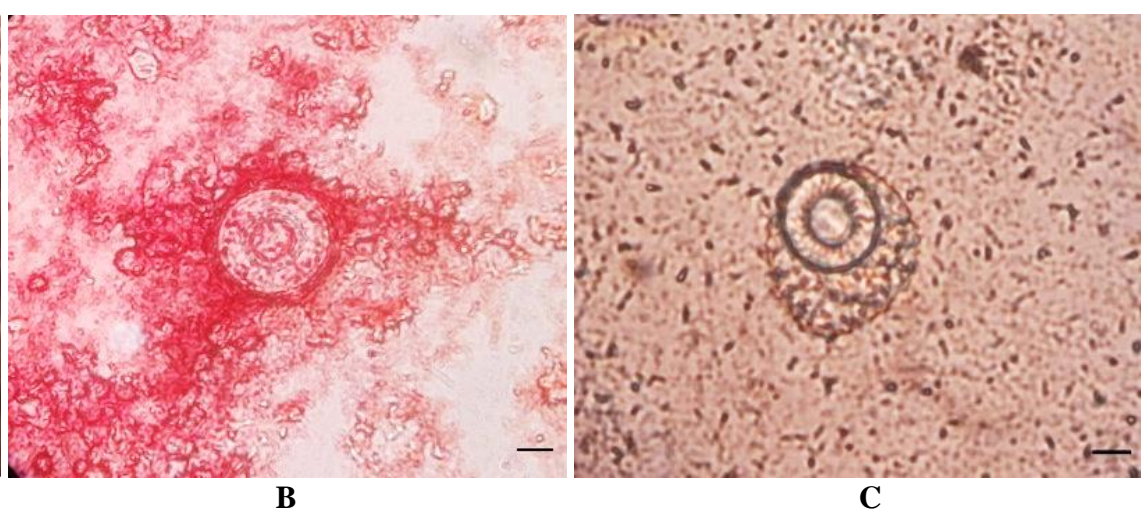

B
$\mathbf{C}$

Figure 1. Trichodina sp. collected from the gills of seabass Lates calcarifer. A: 40x magnification; B and C: 100x magnification. (Bar: $\mathrm{A}=500 \mu \mathrm{m} ; \mathrm{B}$ and $\mathrm{C}=50 \mu \mathrm{m})$ 


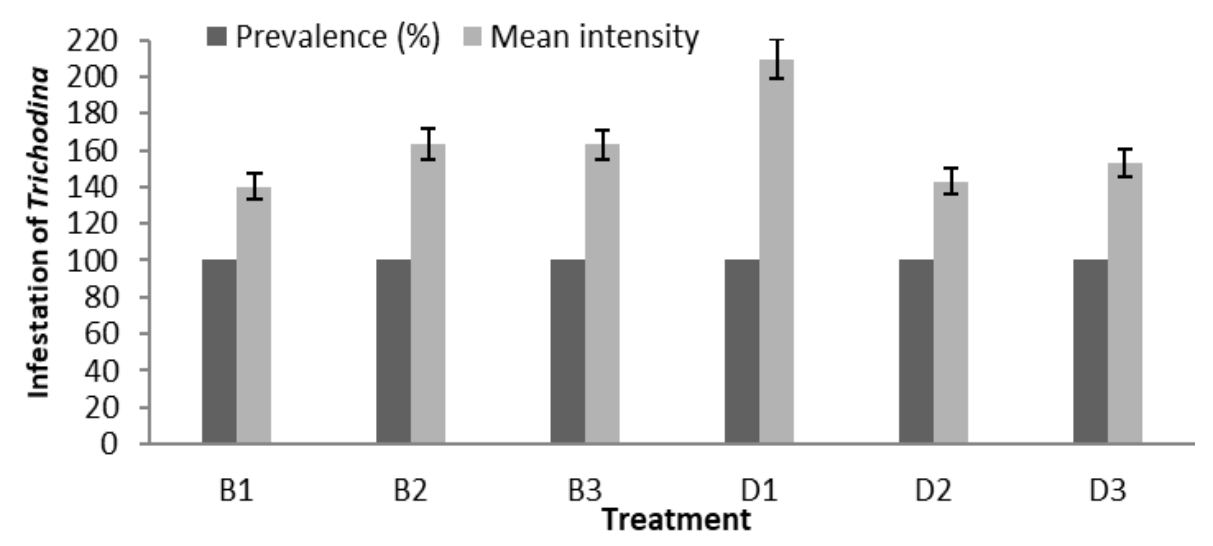

Figure 2. Prevalence and mean intensity of Trichodina sp. on infected seabass Lates calcarifer (B) fish naturally infected with Trichodina sp.; (D) fish naturally infected with Trichodina sp. and injected with Aeromonas caviae)

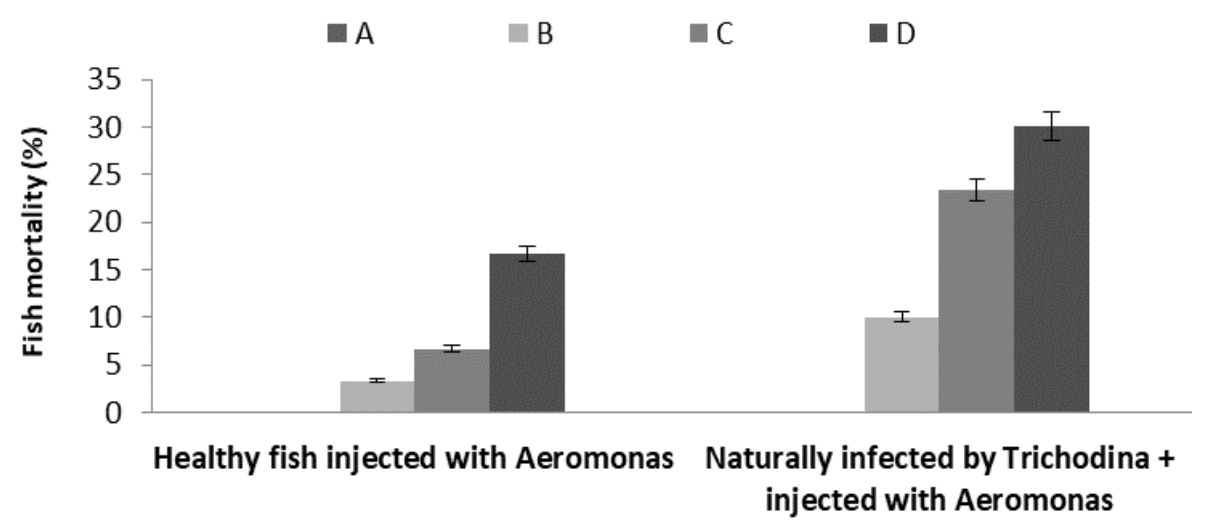

Figure 3. Pathogenicity of Aeromonas caviae, A) control; (B) $10^{5} \mathrm{CFU} / \mathrm{mL}$; (C) $10^{7} \mathrm{CFU} / \mathrm{mL}$; (D) $10^{9} \mathrm{CFU} / \mathrm{mL}$, with standard error

\section{Appearance and physiology of seabass $L$. calcarifer infected by $A$. caviae}

After being infected with A. caviae, fish behavior and morphology were also observed. The clinical symptoms and morphological appearance of fish after the A. caviae infection are presented in Figure 4 and Tables 5 and 6 . In the first 24-hours experiment, fish from all infection treatments exhibited lethargy. Fish infected with A. caviae began to show appetite in 2-3 days after the experiment began, whereas fish naturally infected with Trichodina sp. and injected with $A$. caviae had significantly reduced appetite by day-3. Slow reflexes and fast move on the operculum were expressed on fish infected with A. caviae. Fish with infection of Trichodina sp. and injected with $A$. caviae appeared to swim weakly on the surface and had fast operculum move on day-3 of the experiment. Fish infected with $A$. caviae, demonstrated damages to the operculum and body surface (Figures 4.A, 4.B and 4.C), damage to the eyeball, bleeding in the abdomen (Figures 4.D and 4.E), and the appearance of profuse yellowish spots on the gills (Figure 4.F).
Percentages of symptoms recorded based on observation time show a sequence of severity after injection with Aeromonas for single infection and coinfected fish. All fish in the infection treatments showed lethargy after 24 hours (single infection) and 24-48 hours (co-infection) during the adaptation phase. In the single infection, $62.50 \%$ of the fish showed an appetite and swam slowly, and $37.50 \%$ were still lethargic after 48-72 hours. After 72 hours, $70.83 \%$ of fish showed changes in reflex and slow gill/operculum movement with appetite maintained, and $29.16 \%$ were still lethargic. Of the fish with co-infection, $58.33 \%$ swam up and down in the tank, and $41.66 \%$ were still lethargic after 48 hours. Moreover, $83.33 \%$ lacked appetite and swimming up-down, and $6.66 \%$ were still lethargic by 72 hours. While $95.83 \%$ swam weakly with rapid gill/operculum movement and appetite maintained and $4.16 \%$ were still lethargic after more than 73 hours experiment began. 


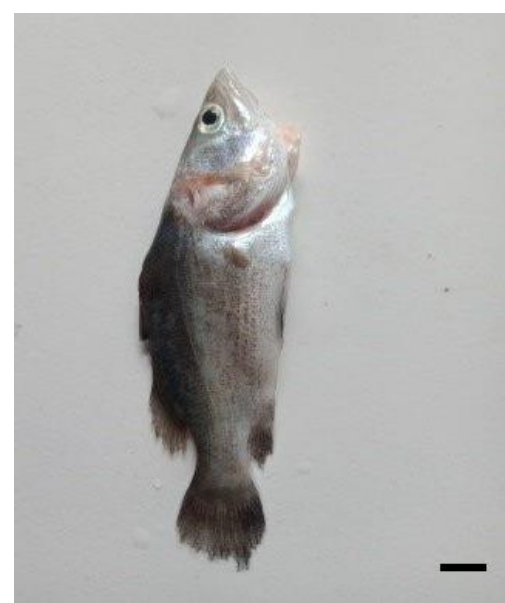

A

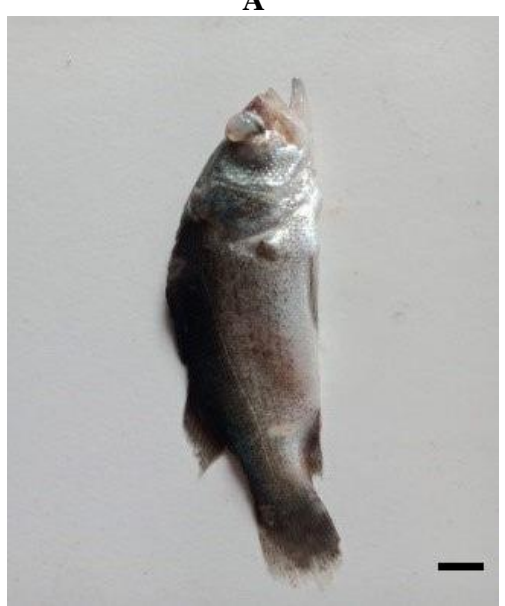

D

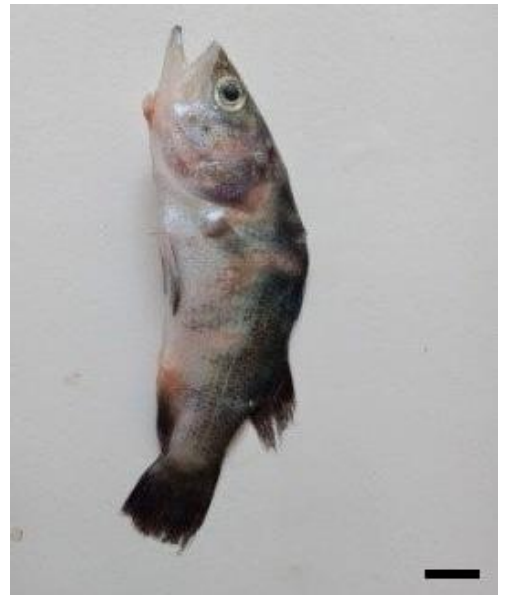

B

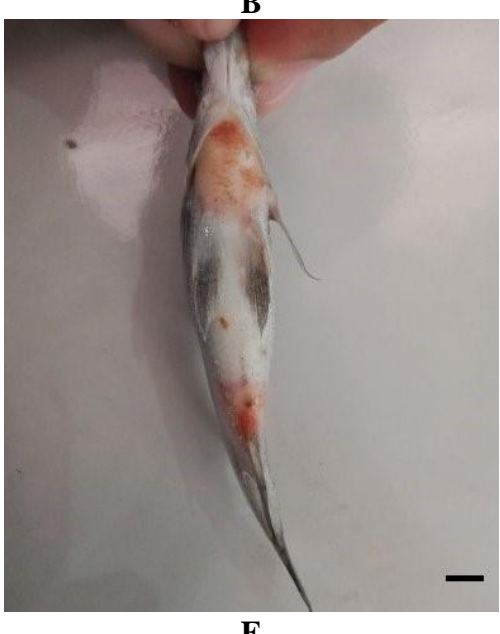

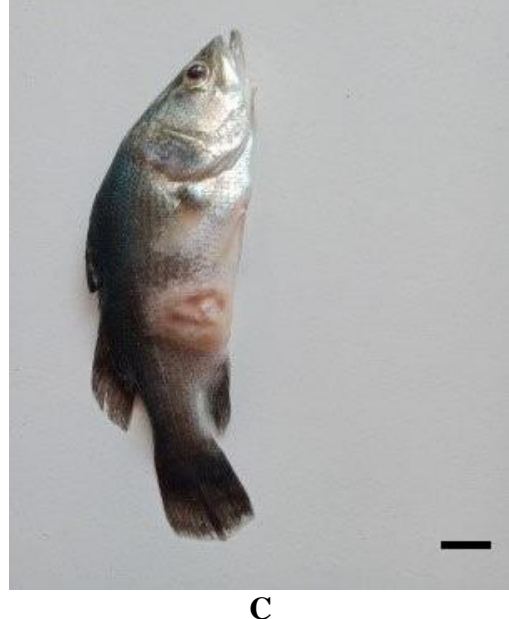

C

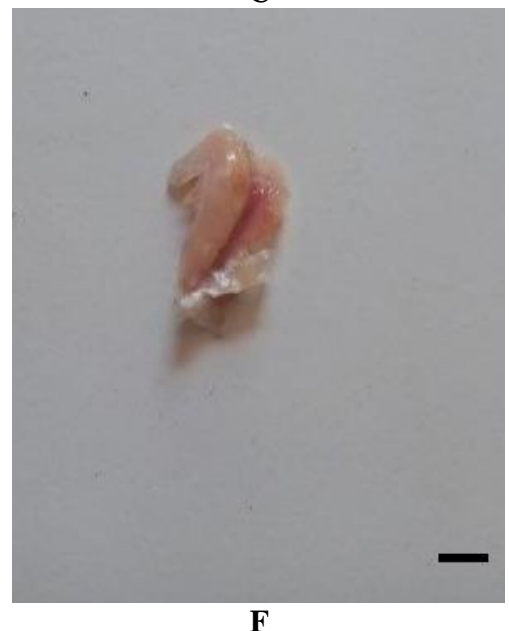

Figure 4. Damage to organs of Asian seabass Lates calcarifer after artificial infection with Aeromonas caviae. A. Operculum; B and C. Body surface; D. Eye; E. Bleeding; and F. Gills. Bar: $1 \mathrm{~cm}$

Table 5. Physiology of healthy seabass Lates calcarifer after injection with Aeromonas caviae

\begin{tabular}{|c|c|c|}
\hline 24 - 48 hours & 48 - 72 hours & $>72$ hours \\
\hline $\begin{array}{l}\text { Lethargic on the tank bottom } \\
(100 \%)\end{array}$ & $\begin{array}{l}\text { Appetite maintained and slow swimming }(62.50 \%) \text {, } \\
\text { lethargic }(37.50 \%)\end{array}$ & $\begin{array}{l}\text { Reflex changes and slow gill/operculum } \\
\text { movement }+ \text { appetite maintained } \\
(70.83), \text { lethargic }(29.16 \%)\end{array}$ \\
\hline
\end{tabular}

Table 6. Physiology of naturally infected seabass L. calcarifer by Trichodina sp. after injection with Aeromonas caviae

\begin{tabular}{llll}
\hline \multicolumn{1}{c|}{$\mathbf{2 4}$ hours } & \multicolumn{1}{c}{$\mathbf{4 8}$ hours } & \multicolumn{1}{c}{ Day 2-3 } & \multicolumn{1}{c}{$>$} \\
\hline Lethargic on the tank & Swimming up and down & Lack of appetite + swimming & Swimming weakly and rapid gill \\
bottom $(100 \%)$ & $(58.33 \%)$, lethargic $(41.66 \%)$ & $\begin{array}{l}\text { up and down }(83.33 \%), \\
\text { lethargic }(6.66 \%)\end{array}$ & $\begin{array}{l}\text { /operculum movement }+ \text { appetite } \\
\text { maintained }(95.83 \%), \text { lethargic }(4.16 \%)\end{array}$ \\
\hline
\end{tabular}

\section{Blood profile of seabass after the experiment}

Blood profile observation was also conducted after the experiment to analyze the impact of infection. The blood profile analyses are presented in Figures 5 and 6.

The no-infection treatment recorded the highest erythrocyte concentration $\left(8 \times 10^{10} \mathrm{~mm}^{-3}\right.$ cells $)$, whereas the fish co-infected with Trichodina sp. and A. caviae had the lowest $\left(5.2 \times 10^{10} \mathrm{~mm}^{-3}\right.$ cells). The highest leukocyte concentration was found in fish co-infected with Trichodina sp. and A. caviae $\left(8.4 \times 10^{8} \mathrm{~mm}^{-3}\right.$ cells $)$ while the lowest was in the control $\left(3.7 \times 10^{8} \mathrm{~mm}^{-3}\right.$ cells $)$. However, the between treatment differences in erythrocyte and leukocyte concentrations were not statistically significant $(\mathrm{P}>0.05)$. 


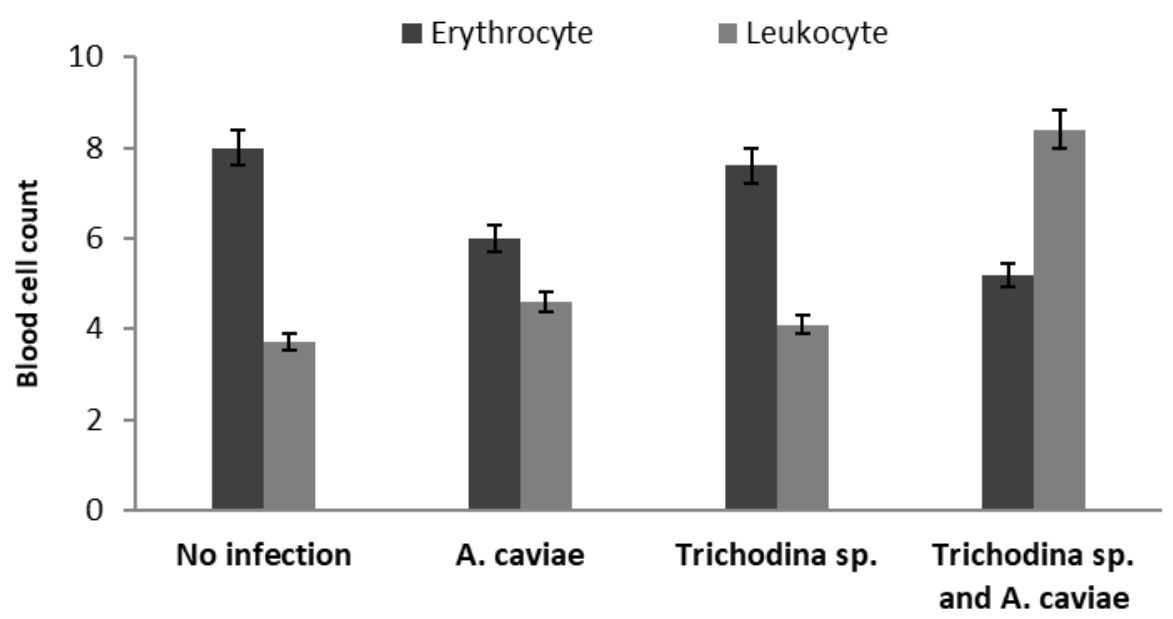

Figure 5. Erythrocyte and leukocyte counts of seabass Lates calcarifer after the experiment (Erythrocyte x $10^{10} \mathrm{~mm}^{-3}$ cells; Leukocyte $\mathrm{x}$ $10^{8} \mathrm{~mm}^{-3}$ cells) with standard error

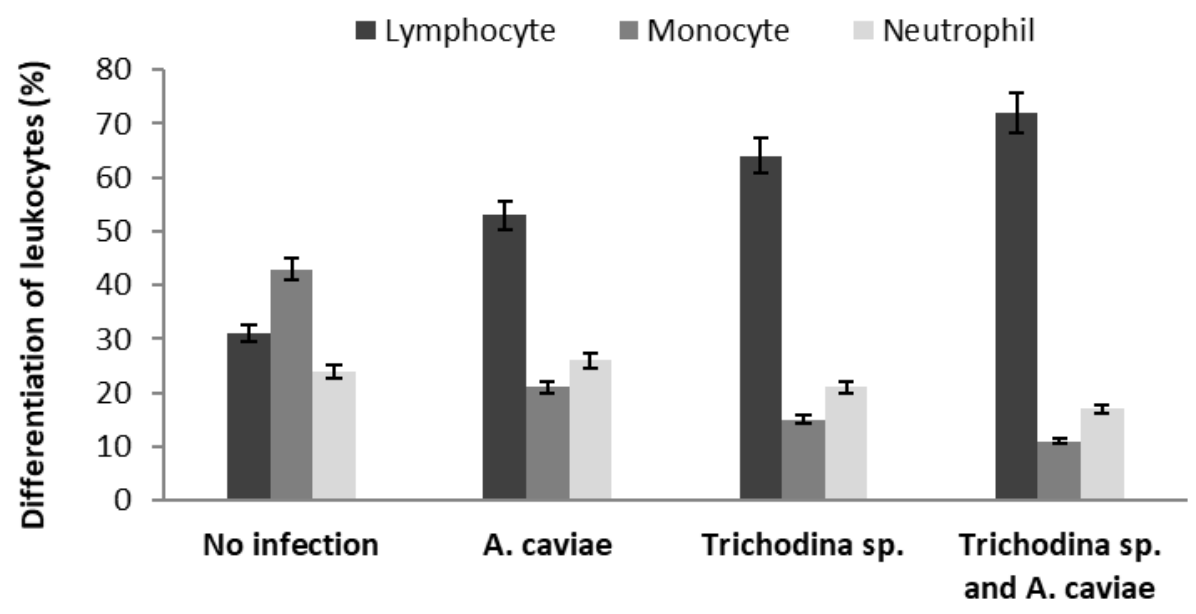

Figure 6. Leukocyte differentiation in seabass Lates calcarifer at the end of the experiment with standard error

Lymphocytes were the most abundant leukocyte cells found in the blood of experimental fish, and monocytes the least. The highest lymphocyte counts were found in fish coinfected with Trichodina sp. and A. caviae, while the noinfection treatment had the lowest $(\mathrm{P}<0.05)$. The statistical test confirmed lymphocyte variable has a good model of regression with a coefficient of determination close to $1(0.97)$ and the calculated $\mathrm{F}>$ the $\mathrm{F}$ table. Monocyte and neutrophil counts were not statistically different between the four treatments $(\mathrm{P}>0.05)$. Blood cell appearance and leukocyte differentiation are provided in Figure 7.

\section{Histopathological of seabass $L$. calcarifer after the experiment}

Histopathological observation is presented quantitatively via tissue damage scoring (Tables 8 and 9). The scoring results demonstrated a significant difference for every treatment $(\mathrm{P}<0.05)$. The result of regression analysis shows a good model with a coefficient of determination $>0.9$ and the calculated $\mathrm{F}>$ the $\mathrm{F}$ table, indicate the independent variable has a significant effect on the dependent variable.

Histopathological observation discovered damage on the gills, liver, kidney, skin, and muscles of seabass $L$. calcarifer in all treatments except the no-infection treatment, characterized by the presence of inflammatory cells, inflammation, necrosis of melano-macrophages, and vacuoles in the observed tissue (Figures 8 and 9). The noninfected fish showed no cell inflammation and necrosis. Healthy fish had very small signs of hemorrhage in the liver and gills (Figures 8.B and 8.C), tiny hemorrhages, and melano-macrophages in the kidneys (Figure 7.A). The coinfection treatment caused the most severe damage to organs, more than single infections with either $A$. caviae (Table 7) or Trichodina sp. (Table 8), as indicated by a large number of inflammatory cells, hemorrhages, melanomacrophages, scar tissue, inflammation, and necrosis. 


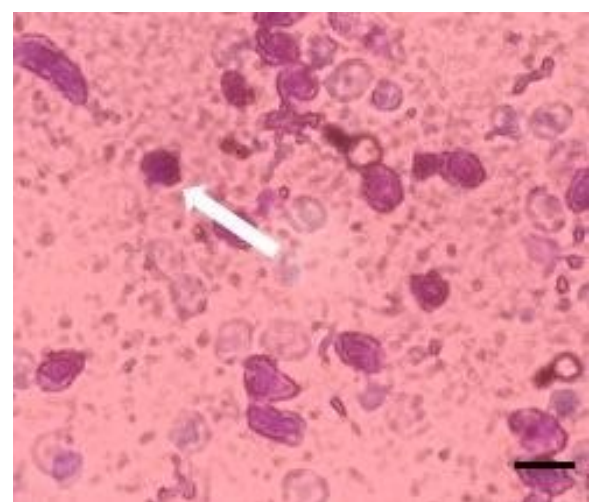

A

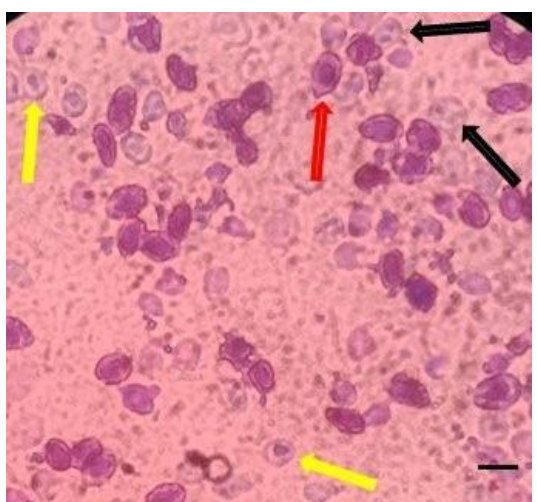

B

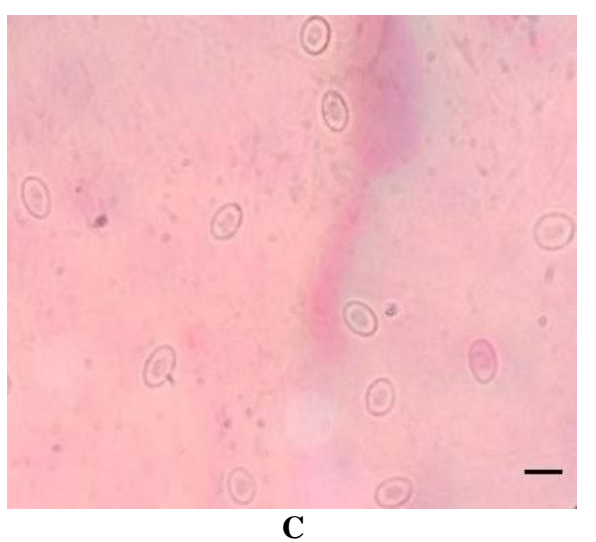

C

Figure 7. Seabass Lates calcarifer blood cells (A and B. Differentiation of leukocytes; C. Erythrocytes before Giemsa staining). Red arrow: Erythrocyte; yellow arrows: Monocyte; black arrows: Neutrophil; white arrow: Lymphocyte. 40x magnification. Bar: $10 \mu \mathrm{m}$

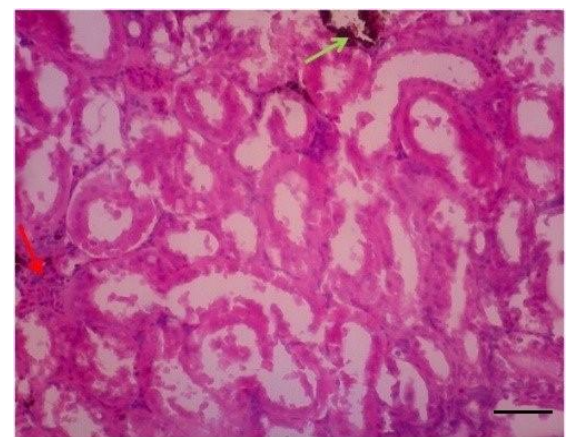

A

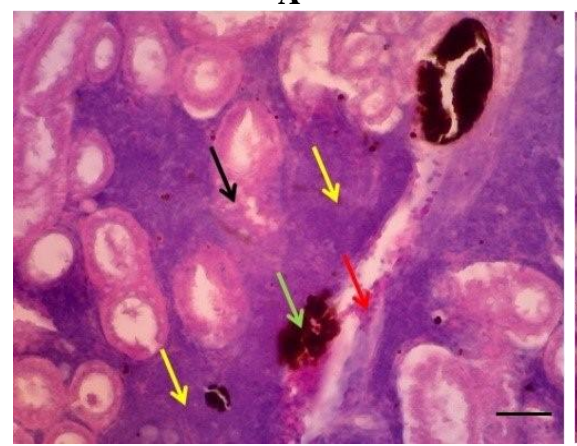

D

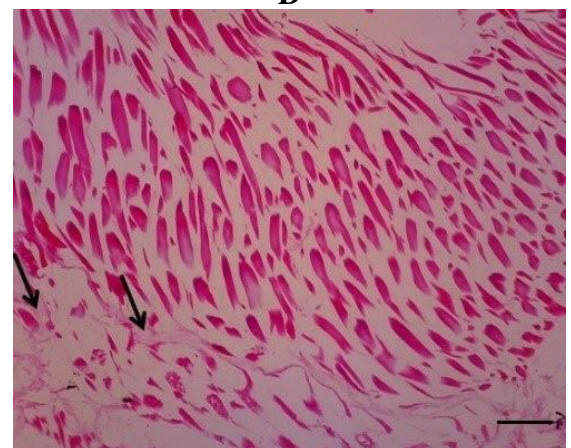

$\mathbf{G}$

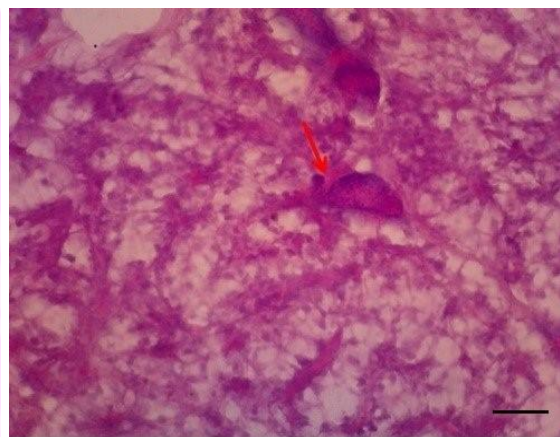

B

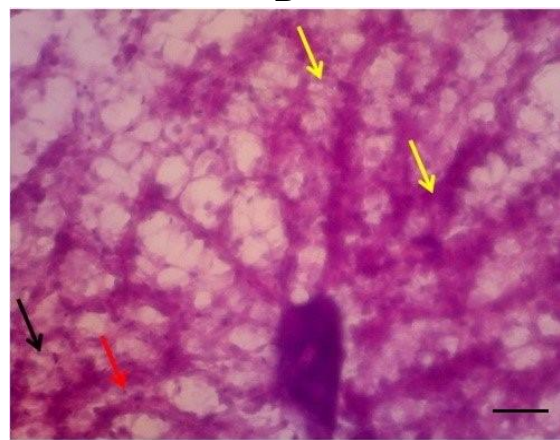

E

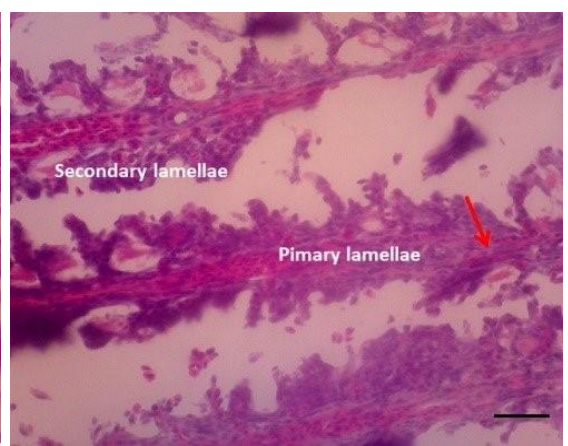

C

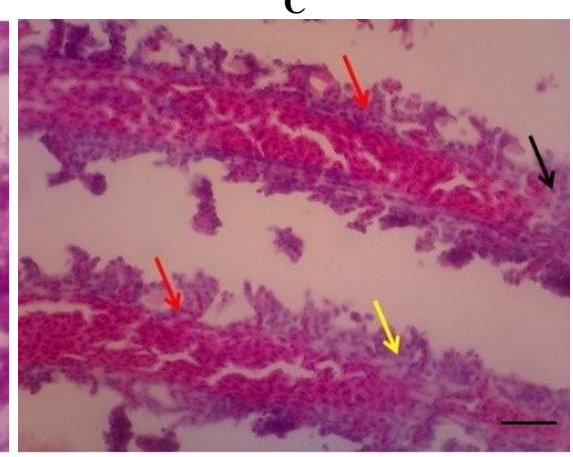

F

Figure 8. Histological images of no-infection seabass Lates calcarifer (A. Kidney; B. Liver; C. Gills) and healthy fish injected with Aeromonas caviae (D. Kidney; E. Liver; F. Gills; G. Skin. Black arrows: necrosis; yellow arrows: inflammation; red arrows: hemorrhage; green arrows: melano-macrophages). 100x magnification and HE staining. Bar: $150 \mu \mathrm{m}$ 


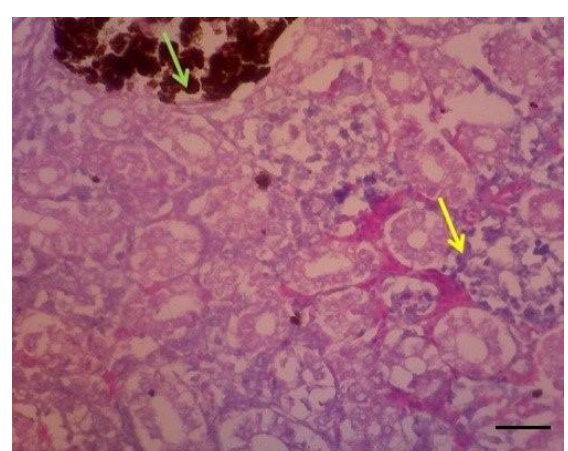

A

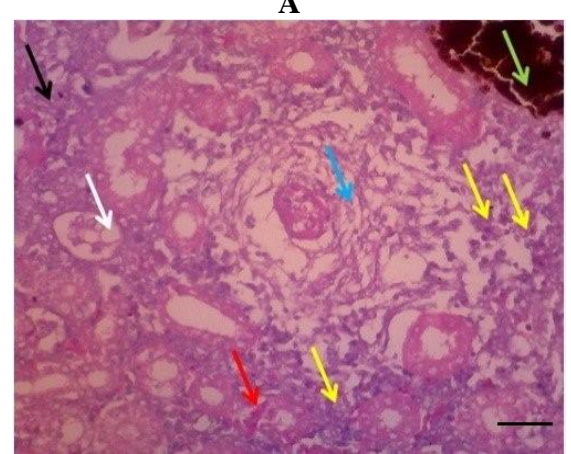

D

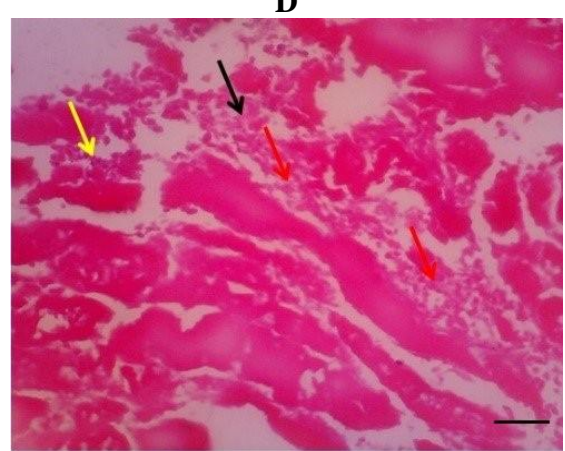

G

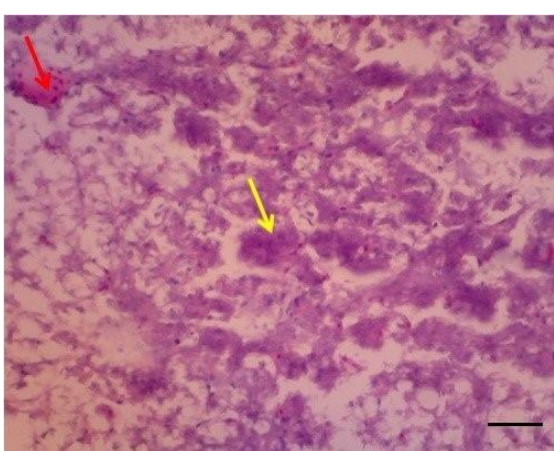

B

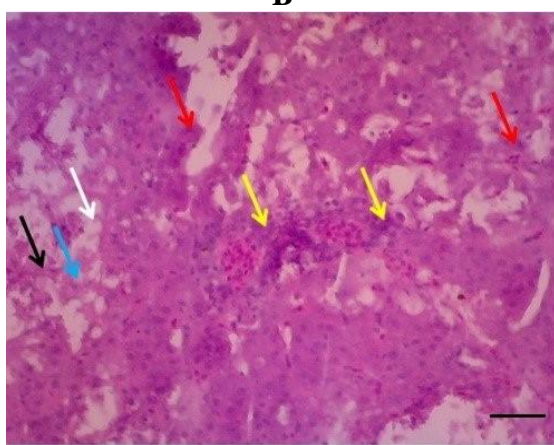

$\mathbf{E}$

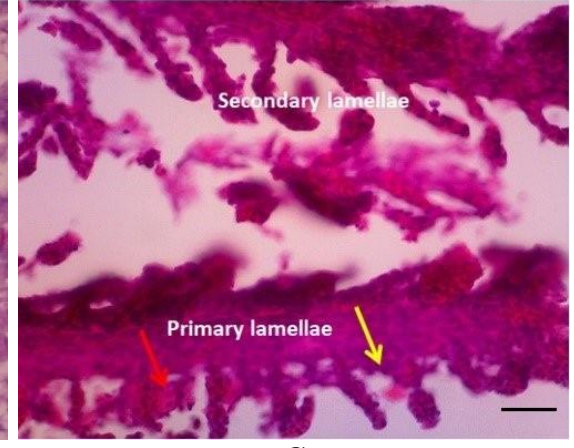

C

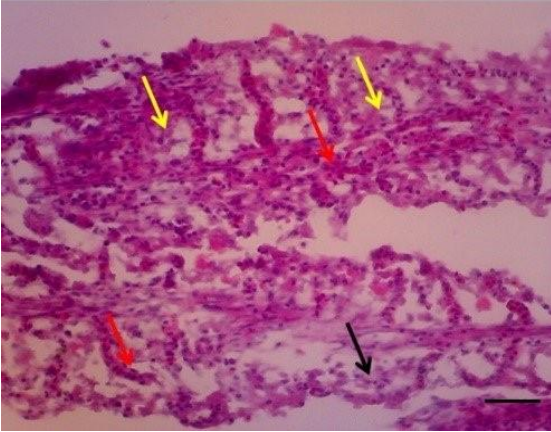

$\mathbf{F}$

Figure. 9. Histological images of seabass Lates calcarifer naturally infected by Trichodina sp. (A. Kidney; B. Liver; C. Gills) and coinfected fish (D. Kidney; E. Liver; F. Gills; G. Skin. Black arrows: necrosis; yellow arrows: inflammation; red arrows: hemorrhage; green arrows: melano-macrophages; blue arrows: scar tissue; white arrows: vacuole). 100x magnification and $\mathrm{HE}$ staining. Bar: $150 \mu \mathrm{m}$

Table 7. Scoring of the tissue damage of no-infection fish and healthy fish injected with Aeromonas caviae

\begin{tabular}{|c|c|c|c|c|c|c|c|}
\hline $\begin{array}{l}\text { Treatments } \\
\text { (infection) }\end{array}$ & Organs & Inflammation & Necrosis & Melano-macrophages & Scar tissue & Vacuole & Hemorrhage \\
\hline \multirow{3}{*}{ No infection } & Kidney & & & + & & & + \\
\hline & Liver & & & & & & + \\
\hline & Gills & & & & & & + \\
\hline \multirow{4}{*}{ A. caviae } & Kidney & +++ & +++ & +++ & & & +++ \\
\hline & Liver & ++ & ++ & & & ++ & ++ \\
\hline & Gills & ++ & ++ & & & & +++ \\
\hline & Skin and muscle & & + & & & & \\
\hline
\end{tabular}

Note: $+=$ mild pathological changes,$++=$ moderate changes, $+++=$ severe pathologic alterations 
Table 8. Scoring of the tissue damage of fish naturally infected with Trichodina sp. and co-infected fish

\begin{tabular}{|c|c|c|c|c|c|c|c|}
\hline $\begin{array}{l}\text { Treatments } \\
\text { (infection) }\end{array}$ & Organs & Inflammation & Necrosis & $\begin{array}{c}\text { Melano- } \\
\text { macrophages }\end{array}$ & Scar tissue & Vacuole & Hemorrhage \\
\hline \multirow[t]{3}{*}{ Trichodina sp. } & Kidney & +++ & & ++ & & & \\
\hline & Liver & ++ & & & & & + \\
\hline & Gills & ++ & & & & & ++ \\
\hline Trichodina sp. and & Kidney & +++ & +++ & ++ & ++ & & ++ \\
\hline \multirow[t]{3}{*}{ Aeromonas caviae } & Liver & +++ & ++ & & + & ++ & ++ \\
\hline & Gills & +++ & ++ & & & & +++ \\
\hline & Skin and muscle & ++ & + & & & & \\
\hline
\end{tabular}

Note: +: mild pathological changes, ++: moderate changes, +++: severe pathologic alterations

\section{Discussion}

In this study, we intended to demonstrate the effects of multiple infections of parasitic ciliated Trichodina sp. and A. caviae on several health indicators (blood profile, physiology, and histopathology of systemic organs) in the Asian seabass L. calcarifer. Ectoparasite observations revealed the specific location of Trichodina sp. as being predominantly in the gills of the seabass $L$. calcarifer. These findings as consonant with the statement by Mizuno et al. (2016) that the site preference of the ectoparasite Trichodina is often on fish body parts that are directly exposed to the external environment like gills and the body surface.

Ectoparasite infestation, in both single and co-infected treatments, was very high, reaching up to $100 \%$ prevalence in all treatments with a mean intensity of 143-209.75. A parasite prevalence of $99-100 \%$ with mean intensity of more than 100 parasites/fish is classified as a very severe infection (Williams and Bunkley 1996). Elucidating the presence of ectoparasites in farmed fish is crucial. Sufardin et al. (2021) described the relation between ectoparasite Trichodina occurrence and bacterial infections, suggesting possible interaction between the occurrence of bacteria and the parasite infection rate on L. calcarifer, especially in fish gills and mucus. A possible explanation would be opportunistic bacteria causing secondary infections by colonizing tissue that was already diseased due to the parasites. Similar scenarios have been reported in the case of fish with Aeromonas (Scott and Bollinger 2014).

Lethal concentrations of $A$. caviae were in the range of $10^{5}-10^{6} \mathrm{CFU} / \mathrm{mL}$, with mean mortality up to $30 \%$ (Table 4). The statistical test showed a significant difference in the pathogenicity of A. caviae in both single infection and coinfection with Trichodina sp. This shows that A. caviae infection can lead to mortality in both previously healthy fish and fish infected with Trichodina sp. Triyaningsih et al. (2014) also conducted pathogenicity tests of Aeromonas infection, finding that a suspension with a density of $1.25 \mathrm{x}$ $10^{6} \mathrm{CFU} / \mathrm{mL}$ resulted in $50 \%$ mortality. This study demonstrates the deadliness of A. caviae infection at a range of concentration levels.

The clinical symptoms of fish infected with A. caviae, either single or co-infected, demonstrated several notable kinds of damage to the surface of the body, gills, and eyeballs. In addition, red patches were observed on the abdomen around the pectoral, pelvic, and anal fins (Figure
4). Weak swimming behavior of the fish was also observed during the experiment (Tables 5 and 6) with the body color classified as pale. The clinical symptoms are similar to the results of Triyaningsih et al. (2014), who found lesions on the body surface and weak movement in fish infected with Aeromonas. Other visible symptoms are torn/malformed dorsal fins and a tendency to swim weakly either at the surface or at the bottom of the aquarium. Zhang et al. (2018) have reported clinical symptoms including dark fins, slow swimming, surface bleeding, abdominal edema, and bleeding in fish infected with Aeromonas. The pathological changes caused by Aeromonas infection are because of aggravated digestion showed as restraint of catalysts, and tissue damage, especially in systemic organ cells (Adel et al. 2017), as representative by histological analysis in a recent study (Figures 8 and 9).

Blood cell counts show the lowest number of erythrocytes was found in co-infected fish, while the highest was in fish in the control treatment. In contrast, the highest leukocyte counts occurred in co-infected fish and the lowest in healthy fish (Figure 5). An overview of blood and physiological markers could be utilized to recognize probable environmental hazards to the health of aquatic animals due to infectious diseases (Burgos-Aceves et al. 2018). Blood in the fish body is associated with the content of serum proteins and could be an indicator of the enhanced fish immune system, and play a vital role in recognizing natural antigens which exist in the skin, systemic organ and found in the plasma of fish (Magnadottir 2010; Uribe et al. 2011). Meanwhile, the increase in leukocytes is evidence that fish respond to pathogens infecting the body, which has many measures to protect itself from external attack. When the fish receives a pathogen induction such as bacterial infection, cell adhesion could act as a barrier in the body (Guttman and Finlay 2009; Howell and de Leeuw 2018).

Observation of leukocyte differentiation showed lymphocytes as more abundant than neutrophils and monocytes. The highest proportion of lymphocytes (72\%) was found in the co-infected fish, while the lowest $(31 \%)$ was in healthy fish and the difference was statistically significant. These results reveal the presence of $A$. caviae as induction of infection in fish after Trichodina sp. primary infection. In healthy fish, monocytes formed the highest proportion of the leukocyte cell population (42\%), while the lowest was neutrophils $(24 \%)$, but they were not 
statistically different (Figure 6). These results suggest a fairly rapid increase in lymphocytes with lower proportions of monocytes and neutrophils in co-infected fish. Lymphocytes are known to play a role in fighting pathogenic infections in the body. Macrophages and lymphocytes play a central role in host defense (Alejo and Tafalla 2011). Evaluation of the neutrophil function is necessary for the assessment of the general health of fish (Cerezuela et al. 2012), with various phagocytic, bactericidal, and respiratory burst activities. It is important to know their usefulness for the assessment of fish health (Vallejos-Vidal et al. 2016).

In the assessment of fish health, histopathology has been widely applied for the study of pathological alterations due to the biological infectious agent as biological markers (Forouhar et al. 2018). In this study, additional pathological changes due to infection with Trichodina sp. and A. caviae on $L$. calcarifer were noted. The impact of histology on fish organs was recorded in several analyzes of changes in tissue pathology, namely gills, liver, kidney, skin, and muscles. The quantification of tissue damage demonstrated statistically significant differences $(\mathrm{P}<0.05)$ between treatments. The control treatment showed no significant damage to either gills, kidneys, or liver (Figures 8A, 8B, and 8C). However, fish organs that had a single infection with Trichodina sp. displayed an accumulation of inflammatory cells in the gills, kidneys, and liver; in addition, melano-macrophages were found in the kidneys and hemorrhage in the liver and gills. Fish organs of fish single-infected by A. caviae, especially the kidneys, suffered various types of damage, namely accumulation of inflammatory cells, melanomacrophages, hemorrhage, and necrosis. Co-infection of Trichodina sp. and A. caviae contributed to more severe damage to the kidneys and liver (Figures 9D and 9E) than single infection treatment, especially accumulation of inflammatory cells and scar tissue. In addition, accumulation of inflammatory cells was found in all fish from both single infected and co-infected treatments. Histopathologically, the damage observed on the body surface and gills of infected fish was a clear sign of injury due to the discharge of bacterial toxins and septicemia. Also, large melano-macrophages might be indicative of a defensive response of hematopoietic tissues against free radical damage caused by Aeromonas virulence (Kathirkaman et al. 2018).

Our findings reveal that a single infection of Trichodina sp. only generated the accumulation of inflammatory cells and some hemorrhage, whereas co-infection with A. caviae contributed to other pathological changes such as inflammation, necrosis, vacuoles, melano-macrophages, and scar tissue. Similar results were reported by Moustafa et al. (2020) with necrosis, inflammation, and melanomacrophages in found tilapia liver due to Aeromonas infection. Also, similar experiments on black carp revealed hemorrhaging and severe tissue damage (Zhang et al. 2018). The accumulation of macrophages in the kidney and other systemic organs is associated with immune response to pathogen materials through phagocytosis (Steinel and Bolnick 2017).
Overall, the study reveals that co-infection of parasites and pathogenic bacteria synergistically affects the health status of farmed fish. A similar synergy between bacteria and parasites increasing the severity of disease symptoms is reported in cases of co-infection with bacteria and ectoparasites in channel catfish (Xu et al. 2012), Nile Tilapia (Xu et al. 2014), and Atlantic salmon (Salmo salar) (Lhorente et al. 2014). Moreover, the parasite load had a significant positive relationship with the richness of the gastrointestinal tract bacterial community in salmon, with significant interactions between parasitic disease and bacterial occurrence in the gastrointestinal tract (Vasemägi et al. 2017). Further, co-infection of two or more pathogens may affect disease severity, and is considered highly likely to further reduce the beneficial effect of vaccination compared to a single infection (Figueroa et al. 2017).

Recent studies attest to the influence of pathological changes on the strong associations between microorganisms. Decreased immunity is also suspected of playing a vital role in the physiological response of the fish body. Tkachenko et al. (2014) describe the damaging effect of the pathogenic bacterial infection in the host tissues as in part associated with oxidative stress induction.

In this study, we revealed the effects of single infection and co-infection of Trichodina sp. and A. caviae on the seabass L. calcarifer. Single infection of Trichodina sp. results in a low accumulation of inflammatory cells and hemorrhage in several organs. Meanwhile, the co-infection of Trichodina sp. and A. caviae contributes to severe damage visible through blood profiling and organ histopathology, indicated by a large and readily detected increase in lymphocytes and significant pathological changes in targeted tissues. The pathogenicity of $A$. caviae becomes more virulent in co-infection with Trichodina sp. than as sole infecting agent.

\section{ACKNOWLEDGEMENTS}

The authors would like to thank The Indonesian Ministry of Education and Culture and the Directorate General of Higher Education Indonesia for funding under the Masters towards Doctoral Education for Excellent Undergraduates (PMDSU) Scholarship Program. This study was funded by grant No. 1517/UN4.22/PT.01.03/ 2020.

\section{REFERENCES}

Abdel-Latif HMR, Dawood MAO, Menanteau-Ledouble S, El-Matbouli M. 2020. The nature and consequences of co-infections in tilapia: A review. J Fish Dis 43: 651-664. DOI: 10.1111/jfd.13164.

Adel M, Dadar M, Khajavi SH, Pourgholam R, Karimí B, Velisek J. 2017. Hematological, biochemical and histopathological changes in Caspian brown trout (Salmo trutta caspius Kessler, 1877) following exposure to sublethal concentrations of chlorpyrifos. Tox Rev 36: 73-79. DOI: 10.1080/15569543.2016.1230631.

Alejo A, Tafalla C. 2011. Chemokines in teleost fish species. Dev Comp Immunol 35: 1215-1222. DOI: 10.1016/j.dci.2011.03.011.

Austin B, Austin DA. 2012. Bacterial Pathogens: Disease of Farmed and Wild Fish, 5th eds. Springer, Germany. 
Burgos-Aceves MA, Cohen A, Smith Y, Faggio C. 2018. MicroRNAs and their role on fish oxidative stress during xenobiotic environmental exposures. Ecotoxicol Env Saf 148: 995-1000. DOI: 10.1016/j.ecoenv.2017.12.001.

Cerezuela R, Guardiola FA, González P, Meseguer J, Esteban MÁ. 2012. Effects of dietary Bacillus subtilis, Tetraselmis chuii, and Phaeodactylum tricornutum, singularly or in combination, on the immune response and disease resistance of sea bream (Sparus aurata L.). Fish Shell Immunol 33: 342-349. DOI: 10.1016/j.fsi.2012.05.004.

Espinosa C, Esteban MA, Cuesta A. 2019. Dietary administration of PVC and PE microplastics produces histological damage, oxidative stress and immunoregulation in European seabass (Dicentrarchus labrax L.) Fish Shell Immunol 95: 574-583. DOI: 10.1016/j.fsi.2019.10.072.

Figueroa C, Bustos P, Torrealba D, Dixon B, Soto C, Conejeros P, Gallardo JA. 2017. Coinfection takes its toll: Sea lice override the protective efects of vaccination against a bacterial pathogen in Atlantic salmon. Sci Rep 7: 17817. DOI: 10.1038/s41598-017-18180-

Forouhar VM, Mohamadi YA, Hedayati A, Faggio C. 2018 Histopathological lesions and toxicity in common carp (Cyprinus carpio L. 1758) induced by copper nanoparticles. Microsc Res Tech 81: 724 - 729. DOI: 10.1002/jemt. 23028 .

Goda AMAS, Ahmed SR, Nazmi HM, Aboseif A, Taha MKS, Fadda SH, Baromh MZ, El-Haroun E, Davies S. 2020. Assessment of a high protein distillers dried grain (HP-DDG) augmented with phytase in diets for European seabass, Dicentrarchus labrax fingerlings on growth performance, hematological status, immune response and related gut and liver histology. Aquaculture 529: 735617. DOI: 10.1016/j.aquaculture.2020.735617.

Guttman JA, Finlay BB. 2009. Tight junctions as targets of infectious agents. Biochimica et Biophysica Acta (BBA) - Biomembr 1788 : 832-841. DOI: 10.1016/j.bbamem.2008.10.028

Howell K, de Leeuw E. 2018. Cell adhesion properties of human defensins. Biochem Biophys Res Commun 502: 238-242. DOI 10.1016/J.BBRC.2018.05.150

Ibraheem AS, Önalan S, Arabaci M. 2017. Investigation of zoonotic disease pathogens (Aeromonas hydrophila, Pseudomonas fluorescens, Streptococcus iniae) seen in carp farms in the Northern Iraq-Erbil region by molecular methods. AIP Conf Proc 1833 (1): 020077-1020077-7. DOI: 10.1063/1.4981725.

Irmawati, Umar MT, Husain AAA, Malina AC, Kadir NN, Alimuddin. 2020. Distribution and character of Asian seabass (Lates calcarifer Bloch, 1970) in South Sulawesi. IOP Conf Ser: Earth Environ Sci 564: 012011. DOI: 10.1088/1755-1315/564/1/012011.

Kathirkaman P, Ayyaru G, Serelathan MV, Singaravel V, Gunasekaran T. 2018. Innate immunological responses of Asian seabass, Lates calcarifer (Bloch, 1790) for experimentally challenged Aeromonas hydrophila infection. Comp Clin Pathol 27: 927-931. DOI: 10.1007/s00580-018-2683-8.

Lhorente JP, Gallardo JA, Villanueva B, Carabaňo MJ, Neira R. 2014. Disease resistance in Atlantic Salmon (Salmo salar): Coinfection of the intracellular bacterial pathogen Piscirickettsia salmonis and the sea louse Caligus rogercresseyi. PLoS One 9 (4): e95397. DOI: 10.1371/journal.pone.0095397.

Li J, Ni XD, Liu YJ, Lu CP. 2011. Detection of three virulence genes alt, ahp and aerA in Aeromonas hydrophila and their relationship with actual virulence to zebrafish. J Appl Microbiol 110: 823-830. DOI: $10.1111 / \mathrm{j} .1365-2672.2011 .04944 . x$

Magnadottir B. 2010. Immunological control of fish diseases. Mar Biotechnol 12 (4): 361-379. DOI: 10.1007/s10126-010-9279-x.

Maharajan A, Kitto MR, Paruruckumani PS, Ganapirya V. 2016. Histopathology biomarker responses in Asian seabass, Lates calcarifer (Bloch) exposed to copper. J Basic Appl Zool 77: 21-30. DOI: 10.1016/j.jobaz.2016.02.001

Mangunwardoyo W, Ismayasari R, Riany E. 2010. Uji patogenisitas dan virulensi Aeromonas hydrophila stanier pada ikan nila (Oreochromis niloticus Lin.) melalui postulat Koch. Jurnal Riset Akuatia 5 (2): 245 255. DOI: 10.15578/jra.5.2.2010.145-255. [Indonesian]

Martins ML, Cardoso L, Marchiori N, de Pádua SB. 2015. Protozoan infections in farmed fish from Brazil: Diagnosis and pathogenesis. Revista Brasileira de Parasitologia Veterinária 24: 1-20. DOI 10.1590/S1984-29612015013.

Moustafa EM, Dawood MAO, Assar DH, Omara AA, Elbialy ZI, Farrag FA, Shukry M, Zayed MM. 2020. Modulatory effects of fenugreek seeds powder on the histopathology, oxidative status, and immune related gene expression in Nile tilapia (Oreochromis niloticus) infected with Aeromonas hydrophila. Aquaculture 515: 734589. DOI: 10.1016/j.aquaculture. 2019.734589.

Mizuno S, Urawa S, Miyamoto M, Hatakeyama M. 2016. The epidemiology of the Trichodinid Ciliate Trichodina truttae on hatchery-reared and wild salmonid fish in Hokkaido. Fish Pathol 51 (4): 199-209. DOI: $10.3147 /$ jsfp.51.199.

Scott SJ, Bollinger TK. 2014. Flavobacterium columnare: An important contributing factor to fish die-off in southern lakes of Saskatchewan, Canada. J Vet Diagn Investig 26: 832-836. DOI: 10.1177/1040638714553591.

Steinel NC, Bolnick DI. 2017. Melanomacrophage centers as a histological indicator of immune function in fish and other poikilotherms. Front Immunol 8: 827-827. DOI: 10.3389/fimmu.2017.00827.

Sufardin, Sriwulan, Anshary H. 2021. Bacteria associated with Trichodina sp. infection of barramundi, Lates calcarifer in a fish farm in South Sulawesi, Indonesia. AACL Bioflux 14 (1): 643-654.

Surat Keputusan Badan Karantina Ikan Pengendalian Mutu dan Keamanan Hasil Perikanan. 2015. Petunjuk Teknis Pemantauan Hama dan Penyakit Ikan Karantina. Badan Karantina Ikan Pengendalian Mutu dan Keamanan Hasil Perikanan, Jakarta. [Indonesian]

Tantry TA, Nazir R, Chishti MZ, Ahmad F, Dar GH, Dar JS. 2016. A report on the incidence of Trichodina heterodentata from fishes of Jammu, J\&K India. J Parasitic Dis 40 (2): 524-527. DOI: $10.1007 / \mathrm{s} 12639-014-0538-\mathrm{Z}$

Tkachenko H, Kurhaluk N, Andriichuk A, Gasiuk E, Beschasniu S. 2014 Oxidative stress biomarkers in liver of sea trout (Salmo trutta m. trutta L.) affected by ulcerative dermal necrosis syndrome. Turk J Fish Aquat Sci 14: 391-402. DOI: 10.4194/1303-2712-v14_2_09.

Triyaningsih, Sarjito, Prayitno SB. 2014. Patogenisitas Aeromonas hydrophila yang diisolasi dari Lele Dumbo (Clarias gariepinus) yang berasal dari Boyolali. J Aquat Manag Technol 3 (2): 11-17. [Indonesian].

Uribe C, Folch H, Enríquez R, Moran G. 2011. Innate and adaptive immunity in teleost fish: A review. Vet Med 56 (10): 486-503. DOI: 10.17221/3294-VETMED.

Vallejos-Vidal E, Reyes-López F, Teles M, MacKenzie S. 2016. The response of fish to immune stimulant diets. Fish Shell Immunol 56: 34-69. DOI: 10.1016/j.fsi.2016.06.028.

Vasemägi A, Visse M, Kisand V. 2017. Effect of environmental factors and an emerging parasitic disease on gut microbiome of wild salmonid fish. mSphere 2 (6): e0418-17. DOI: 10.1128/mSphere.00418-17

Wang Z, Zhou T, Gu Z. 2017. New data of two trichodinid ectoparasites (Ciliophora: Trichodinidae) from farmed freshwater fishes in Hubei, China. Eur J Parasitol 60: 50-59. DOI: 10.1016/j.ejop.2017.04.002

Williams EH, Bunkley LW. 1996. Parasites Off Shore Big Game Fishes of Puerto Rico and the Western Atlantic. Puerto Rico. Department of Natural Environmental Resources and University of Puerto Rico, Rio Piedras.

Xu DH, Shoemaker CA, LaFrentz BR. 2014. Enhanced susceptibility of hybrid tilapia to Flavobacterium columnare after parasitism by Ichthyophthirius multifiliis. Aquaculture 430: 44-49. DOI: 10.1016/j.aquaculture.2014.03.041.

$\mathrm{Xu}$ DH, Shoemaker CA, Klesius PH. 2012. Ichthyophthirius multifiliis as a potential vector of Edwardsiella ictaluri in channel catfish. FEMS Microbiol Lett 329 (2): 160-167. DOI: 10.1111/j.15746968.2012.02518.x.

Yu J, Koo BH, Kim DH, Park SW. 2015. Aeromonas sobria infection in farmed mud loach (Misgurnus mizolepis) in Korea, a bacteriological survey. Iran J Vet Res 16 (2): 194-201.

Zafran, Rosa D, Mahardika K. 2019. Prevalensi ektoparasit pada ikan budidaya di karamba jaring apung di Teluk Kaping, Buleleng, Bali. J Fish Mar Res 3 (1): 32 - 40. DOI: 10.21776/ub.jfmr.2019.003.01.4. [Indonesian]

Zhang X, Shen Y, Xu X, Zhang M, Bai Y, Miao Y, Fang Y, Zhang J, Wang R, Li J. 2018. Transcriptome analysis and histopathology of black carp (Mylopharyngodon piceus) spleen infected by Aeromonas hydrophila. Fish Shell Immunol 83: 330-340. DOI: 10.1016/j.fsi.2018.09.047 